Bol. Acad. peru. leng. 50. 2010 (35-63)

\title{
LOS COMENTARIOS DEL INCA Y LA LEYENDA DEL PERÚ
}

\author{
LES COMMENTAIRES DE L'INCA ET LA LÉGENDE DU
}

\section{PÉROU}

\section{THE INCA'S COMMENTS AND THE LEGEND OF PERU}

\author{
Óscar Coello \\ Universidad Nacional Mayor de San Marcos
}

Resumen:

El presente artículo busca enlazar la leyenda original del Perú con la narración artística del país de los incas que propone Garcilaso en los Comentarios reales. Tras rememorar la leyenda del Perú a inicios del siglo XVI, da cuenta de algunos de los relatos fabulosos que ya venían en el imaginario de los descubridores de América; después, trata del surgimiento de las leyendas híbridas, españolas e indias, que aparecieron tras la toma de Cajamarca. Y ya en el tema central, apoyado en el relato previo de la búsqueda de la Florida o leyenda de la Fuente de la Juventud que hace el Inca, se destacan algunos rasgos artísticos de la hermosa leyenda del Perú que se despliega en los Comentarios reales.

Résumé:

Le présent article a pour but de lier la légende originale du Pérou avec la narration artistique du pays des Incas proposée par Garcilaso dans les Commentaires réels. Après avoir remémoré la légende du Pérou au début du XVIe siècle, nous révèlent que certains récits fabuleux étaient déjà 
présents dans l'imaginaire des découvreurs de l'Amérique; après, il traite du surgissement des légendes hybrides, espagnoles et indiennes, qui sont apparues après la prise de Cajamarca. Et, dans le sujet central, soutenu sur le récit préalable de la recherche de la Floride ou la légende de la Fontaine de la Jeunesse qui fait l'Inca, se détachent quelques traits artistiques de la belle légende du Pérou qui se déploie dans les Commentaires réels.

\section{Abstract:}

This article seeks to connect the original legend of Peru with the artistic narration of the Inca's country that Garcilaso proposes in the Royal Comments. After recalling the legend of Peru at the beginnings of the 16th century, it explains about some fabulous narrations which were already part of the imaginary of the America discoverers. Furthermore, it describes the emergence of the hybrid, Spanish and Indian legends, which appeared after Cajamarca's capture.

Palabras claves:

Inca Garcilaso; Comentarios reales; leyenda; Perú; incas.

Mots clés:

Inca Garcilaso; les Commentaires réels; légende; Pérou; les Incas.

Key words:

Inca Garcilaso; royal Comments; legend; Peru; Incas.

Fecha de recepción: $\quad$ 07/06/2010

Fecha de aceptación: $\quad 30 / 07 / 2010$

«El pasado tiene que ver con nuestros muertos y a ellos no podemos recordarlos con actitud aséptica, científica.»

Hayden White, El texto histórico como artefacto literario

El Inca Garcilaso de la Vega es el Príncipe de las Letras Peruanas. Es el escritor peruano (por cuatro siglos seguidos) más perenne, más estudiado, 
más universal. El año glorioso de 1609, desde una vieja imprenta de Lisboa, propuso al mundo ilustrado de entonces la más hermosa historia de nuestra patria. Los trazos de su pluma han devenido desde entonces en inaprensibles, y tienen el encanto del altar barroco colonial que subyuga sin dejarse atrapar por la explicación. Los Comentarios reales, de este modo, siempre habrán de descubrirse otra vez como la hermosa prosa que solo espera la inacabable contemplación.

\section{La leyenda del Perú}

En el siglo XVI, antes de la llegada de Pizarro, el Perú era una imprecisa leyenda que existía solamente en la imaginación del europeo del Orbis Novus; o, dicho de otro modo, de los poquísimos alucinados españoles que habían estado merodeando por el Caribe o mar de las Antillas, y que el 29 de septiembre de 1513, día del bendito San Miguel, luego de atreverse a cruzar un trecho de selva perdida, alcanzaron a tocar con sus manos el infinito de la Mar del Sur.

El Perú era para ese entonces un dezir, de tan buena ley como el Dorado, como el país de la Canela, como el reino de las Amazonas, como la Atlántida. Un país del delirio que fue cambiando de lugar y de forma según la fantasía de sus buscadores: primero estuvo por Panamá, cuando aún no existía la actual Panamá, sino solo la Tierra Firme o Castilla del Oro. Sin saber dónde estaban parados, los extraviados expedicionarios primero caminaron hacia el Este, y por eso le llamaron a su empresa la Armada del Levante. Después fueron buscando esta tierra de maravilla, por el laberinto de los manglares y por las islas desorientadas que aparecían, cual espejismos, bien hacia el Sur.

Los buscadores de la leyenda del Perú (unos «ciento y tantos», como recuerda El poema del descubrimiento del Perú, escrito en 1538, en el Cuzco, por Diego de Silva y Guzmán ${ }^{1}$ ), para evitar la selva inexpugnable del

1 Coello, Óscar. Los inicios de la poesía castellana en el Perú. [1999]. Lima: PUCP-Fondo Editorial, 2001, 2. ${ }^{\text {a }}$ ed., p. 137. 
Darién, que hacía imposible el paso, bordearon las costas del Pacífico de la actual Colombia, en un par de ridículos y crujientes barquichuelos (el Santiago y el San Cristóbal), enfrentados a vientos ignotos, a un mar que de pronto se quedaba inmóvil (la calmería implacable) y que otras veces rompía en correntadas desconocidas; y, en una noche incierta y miedosa, sin siquiera saberlo, cruzaron la equinoccial o línea del Ecuador, y descubrieron que en este cielo habitaba la Cruz del Sur.

\section{La fundación del Perú}

Luego de deambular por el laberinto de los manglares tumbesinos, un día salieron a unos desiertos ardientes nada más que para volverse a encalavernar; y terminaron acampando en las tinieblas de un horizonte perdido, ya muy lejos de sus casas, siempre con el oído alerta al infortunio, y solo dueños de un temor — que no se $\mathrm{iba}$ - a las adversidades inesperadas.

Al cabo de jornadas que les parecieron interminables por nuestros arenales, una noche se durmieron y despertaron en un vergel deleitoso al borde del refrescante río Chira. Fue en esa desmemoriada mañana, después de la misa del alba en el campamento, en que, teniendo apenas un poco más que su fe ruda, sencilla y pecadora entre las manos, decidieron quedarse aquí para siempre. Y fundaron, entonces, el Perú de la realidad, el Perú de nuestros días.

Fue en un día de María Asunta al Cielo (15 de agosto de 1532); y le pusieron a ese primer pueblo castellano el nombre del arcángel que, en su entender, los cuidaba en tierra tan extraña y enlazaron el nombre del bendito con el nombre del lugar peregrino que andaban buscando: San Miguel del Pirua ${ }^{2}$ (Pi-rua); por un tiempo también usaron el antropónimo

2 Garcilasso de la Vega, el Ynca «Proemio al lector». Primera parte de los commentarios reales, qve tratan del origen de los Yncas, reyes que fueron del Perú, de sv idolatría, leyes, y gouierno en paz y en guerra de sus vidas y conquistas, y de todo lo que fur aquel Imperio 31 su República, antes que los españoles passaran a él. Lisboa: En la oficina de Pedro Crasbeeck. MDCIX, Libro I, Cap. VI, fol. 6r. ${ }^{\circ}$. 
del dueño del valle extraño, San Miguel de Tangarala ${ }^{3}$; que rápido se les cayó de la memoria. Y, más bien, perduró el nombre que la fuerza de su lengua castellana sonorizó por metástasis: San Miguel de Piura; y, después, Piura, a secas.

\section{De cómo el país de los incas se convirtió en el 'Reino del Perú'}

Un tiempo después, cuando los tallanes amigos les revelaron la entrada, y vieron en todo su esplendor lo que hasta entonces no habían visto, creyeron que esa leyenda que los había enajenado desde hacía veinte años atrás a las orillas del nuevo mar descubierto era la leyenda del Perú, que se hacía realidad, que ahora era cierta.

Ese reino del delirio que habían venido buscando, tenía que ser, debía ser este reino de los incas que ahora tocaban con sus manos: por lo increíble, dorado y prodigioso. $\mathrm{Y}$, en una hermosa confusión, el país de los incas fue rebautizado con el nombre del desvarío o el de la leyenda soñada: La leyenda del Reino del Perú.

De esta manera, Pizarro cuando descubrió el Tawantinsuyo implantó de golpe un sueño en el mundo de las verdades de Occidente. Y mostró a los ojos asombrados de Europa, en términos contantes y sonantes, que la alucinación y el delirio eran realidades con las cuales ellos habrían de convivir desde entonces en estas tierras.

\section{Un reino sin nombre}

El país de los incas que se encontraron, en verdad, no tenía un nombre genérico; se nombraba por regiones: el Antisuyo, el Contisuyo, el Collasuyo, el Chinchaysuyo; así lo cuenta el Inca Garcilaso:

$3 \quad$ Fernández de Oviedo, Gonzalo: Historia general $y$ natural de las Indias, Islas $y$ Tierra-Firme del Mar Océano. Madrid: Imprenta de la Real Academia de la Historia, 1855, Libro XLVI, Cap. 11, p. 150.

Bol. Acad. peru. leng. 50(50), 2010 
"... en su lenguage no tuuieron nombre genérico para nombrar en junto los Reynos, y prouincias que sus Reyes naturales señorearon, como dezir España, Italia o Francia, que contiene en sí muchas prouincias. Supieron nombrar [solamente] cada prouincia por su proprio nombre (...) [y] Tauantinsuyu (...) [solo] quiere dezir las quatro partes del mundo".

Mucho tiempo antes, en 1538, lo contaba también así el escritor Diego de Silva y Guzmán, padrino del Inca Garcilaso, en su novela La toma del Cuzco. ${ }^{5}$

\section{El nombre del Perú}

El nombre español del Perú de la leyenda, si bien está documentado desde 1523 (Archivo General de Indias, Contaduría, leg. $\left.n .{ }^{0} 1451\right),{ }^{6}$ hemos dicho que existía desde el esplendor del descubrimiento del Pacífico, aquel día de San Miguel de 1513, cuando Balboa y Pizarro lo tocaron por primera vez.

Leamos a Garcilaso cuando cuenta sobre el nombre del Perú de la leyenda:

"[El nombre]... lo impusieron los de Vasco Núñez de Balboa, que no entraron la tierra a dentro, para tener noticia del nombre Pirua: $y$ no los conquistadores del Perú, porque quinze años antes que ellos fueran a la conquista llamauan Perú los españoles que viuían en Panamá, a toda aquella tierra que corre desde la equinocial al mediodía (...). Algunos dizen que Balboa tuuo relación de cómo

4 Garcilaso de la Vega, Inca, ibíd., Libro I, Cap. V, fol. 4v. ${ }^{0}$.

5 Coello, Óscar. Los orígenes de la novela castellana en el Perú: La toma del Cuzco (1539). Lima: Academia Peruana de la Lengua-Universidad Nacional Mayor de San Marcos, 2008, p. 414-415.

6 Maticorena, Miguel: «El vasco Pascual de Andagoya inventor del nombre del Perú». En: Cielo Abierto. Lima, Vol. II, N. . 5, octubre 1979, pp. 38-42. 
aquella tierra del Perú tenía oro y esmeraldas. Sea así, o no sea, es cierto que auía en Panamá gran fama del Perú (...) de donde consta claro que la imposición del nombre Perú fue mucho antes que la ida de los conquistadores que ganaron aquel imperio".7 (Énfasis nuestro).

\section{De cómo los incas comienzan a ser peruanos}

Cuando nuestros fundadores se encontraron con el país de los incas o con las cuatro partes del mundo o Tawantinsuyo, casi veinte años después, se corrió la llamarada de la noticia del hallazgo 'del Perú y todo lo que había en él comenzó a ser rebautizado con el nombre del desvarío; así, los incas comienzan a ser peruanos, los Andes son peruanos, el oro llega del Perú y todo vale un Perú. Leamos otra vez los Comentarios: "Este nombre fue (...) impuesto por los españoles a aquel imperio de los incas, nombre puesto a caso y no proprio, y por tanto de los indios no conoscido antes, por ser bárbaro tan aborrescido, que ninguno de ellos lo quiere vsar, solamente lo vsan los españoles". 8

Es el Inca repitiendo al padre Blas Valera. Las lecciones de los Comentarios reales, que copio, provienen de la edición de 1609. Por eso, cuando hablamos del Perú de hoy, hablamos en verdad de una creación del mundo occidental.

II. Las leyendas que llegaron a América

El paraíso terrenal

El descubrimiento de la América española está ligado fuertemente a la existencia de leyendas vivas que circulaban como moneda corriente en

7 Garcilaso de la Vega, Inca: ibíd., Libro I, Cap. VI, fol. 6r. ${ }^{0}$ y $6 \mathrm{v}$.

8 Ibíd Libro 1, Cap. VI, fol. 5v. ${ }^{0}$.

Bol. Acad. peru. leng. 50(50), 2010 
el universo, recortado, del hombre europeo de aquella época. ${ }^{9}$ Cristóbal Colón le escribe al papa Borgia, Alejandro VI, diez años después de Guanahaní, y luego del tercer viaje, es decir, en 1502, una carta donde le dice: «Y hice navegación nueva hazia el Austro, adonde yo fallé tierras infinitíssimas y el agua de la mar dulce. Creí y creo aquello que creyeron y creen tantos sanctos y sacros theólogos, que allí en la comarca es el Paraíso Terrenal». ${ }^{10}{ }^{11}$ Porque la sombra del Paraíso siempre lo había ilustrado en sus peregrinaciones por las tierras ignotas. Y siempre pinta el mundo descubierto con esa imagen. El 13 de diciembre de 1492 describe en su Diario la Nueva Tierra de este modo: «Estavan todos los árboles verdes y llenos de fruta, y las yervas todas floridas y muy altas; los caminos muy anchos y muy buenos; los aires eran como en abril en Castilla; cantava el ruiseñor y otros paxaritos...». ${ }^{11}$

Y es que, según el relato de la Sagrada Biblia, el Paraíso terrenal nunca fue borrado de la faz de la tierra, sino solo había sido cercado para la vista del hombre; por eso, a partir de entonces, el hombre siempre lo anduvo buscando y lo busca con viva esperanza. Teólogos serenísimos de la talla de San Isidoro de Sevilla le habían enseñado a la humanidad, desde los siglos VI y VII de nuestra era, que el Paraíso era una verdad geográfica «situada en tierras orientales». ${ }^{12}$

Y en uno de los libros básicos que había leído Cristóbal Colón, el Ymago Mundi (1410), del cardenal y teólogo francés Pierre d'Ailly (Petrus Alliacus), cuyo ejemplar con unas mil anotaciones de puño y letra del Gran Almirante de la Mar Océano, se conserva aún en la Biblioteca Colombina de Sevilla, se lee la letra resuelta del visionario, que pone en el margen: «El

9 Gandía, Enrique de: Historia crítica de los mitos y leyendas de la conquista americana. [1929]. BB. AA.: Centro Difusor del Libro, 1946, pp. 7 y ss.

10 Colón, Cristóbal: «Carta al Papa Alejandro VI. Febrero, 1502. Fuente: LXI.-AGIS. Patronato 295, 44». En: Cristóbal Colón. Textos y documentos completos. Relaciones de viajes, cartas y memoriales. Madrid: Alianza Editorial, 1984, p. 311.

11 Colón, Cristóbal: «Diario del Primer viaje (1942). Jueves, 13 de diziembre». En: Cristóbal Colón. Textos y documentos completos. Relaciones de viajes, cartas y memoriales, p. 80.

12 Isidoro de Sevilla (San): Etimologías. Madrid: Biblioteca de Autores Cristianos, 1983, p. 167. 
Paraíso Terrenal es el lugar más agradable del Oriente, lejano por tierra y mares de nuestro mundo habitable». ${ }^{13} \mathrm{Y}$, hasta la hora de su muerte, lo acompañó la íntima certeza de que el mundo nuevo por él descubierto no era solo terrenal y finito, sino que más bien había llegado por el Poniente al mundo de la tierra viva.

\section{La fuente de la juventud}

Las leyendas que poblaron América desde los días iniciales venían de muy lejos. La Fuente de la Juventud o «fuente que remoçaba a los viejos», ${ }^{14}$ como la llama el Inca Garcilaso en La Florida, cuya búsqueda enloqueció a nuestros fundadores, provenía de un viejo mito sumerio de dos mil años antes de nuestra era. El Pseudo Calístenes la había descrito con minuciosidad ${ }^{15}$ en el Romance de Alejandro y Cristóbal Colón la tenía bien presente en otro de sus libros consultadísimos: el Libro de las Maravillas del mundo, de Sir Jehan de Mandeville. Y si el Paraíso Terrenal estaba en el Nuevo Mundo descubierto, la Fuente de la Juventud también debía estar por aquí, pues Mandeville había conjeturado que aquella fuente de seguro se surtía por canales subterráneos de los manantiales del Paraíso Terrenal: «Es tal la virtud de esta fuente maravillosa que dicen que viene del Paraíso Terrenal». ${ }^{1314 * 16}$ Ya veremos cómo el Inca narra la búsqueda de la Fuente de la Juventud por uno de los que estuvo en la toma de Cajamarca.

\section{Las Antillas, el Brasil y el reino de las Amazonas}

Las Antillas no fueron otra cosa sino que las siete islas o anti-islas (anti-ilhas, en portugués) de las siete Canarias que habían marcado por

13 Àpud: Magasich, Jorge y Jean-Marc de Beet: América mágica. Santiago de Chile: LomEdiciones, 2001, p. 35.

14 Garcilaso de la Vega, Inca: La Florida, Libro I, Cap. II, fol. 3r, .

15 Magasich, Jorge y Jean-Marc de Beer: América mágica, pp. 56-7.

16 Sir Jehan de Mandeville: El libro de las maravillas del mundo. En: Benedeit y Jehan de Mandeville: Libros de maravillas. Madrid: Ed. Slruela, 2002, Cap. XX, p. 190. 
mucho tiempo el Non plus ultra o fin del mundo conocido antes de los grandes viajes. ${ }^{17}$ El Brasil figuró en mapas nórdicos cambiantes cientos de años antes de que los portugueses soñadores lo implantaran en el mundo de las realidades de Occidente. ${ }^{18}$ La tierra de las Amazonas fue referida por Heródoto cinco siglos antes de Jesucristo. Y el Pseudo Calístenes reproduce con fidelidad una carta de una bien plantada jefa amazona al nada pusilánime macedonio Alejandro Magno. ${ }^{19}$ Cientos de años antes de que nuestro Fray Gaspar de Carbajal (15OO-1574) ${ }^{20}$ viera a las amazonas por nuestras selvas de Iquitos, ya Mandeville las describía con minuciosidad:

Más allá de Caldea está Amazonia, la Tierra de Feminia, un reino donde solo viven mujeres. [...] Si paren a un varón, se enojan mucho, y tan pronto como su hijo sepa andar y comer solo, lo mandan con su padre, o lo matan incluso. Si es niña, le quitan un pecho con un hierro candente: si es hija noble, le quitan el izquierdo, para que pueda llevar más fácilmente el escudo, y si es plebeya, el derecho, para que no le impida tirar con el arco, un arte en el que son muy diestras. ${ }^{21}$

\section{Las Siete Ciudades Encantadas}

Narración similar a las anteriores - y muy ligada a la leyenda de las Antillasera la leyenda de las Siete Ciudades Encantadas a las que arribaron siete obispos portugueses luego de salir huyendo de la invasión de los árabes a la Península. Dice la historia fabulosa que, para no volver jamás del sitio alucinante, los obispos quemaron sus naves 22 .

17 Magasich, Jorge y Jean-Marc de Beer: América mágica, pp. 80-1.

18 De Gandía, óp. cit., p. 12 y p. 16, nota P).

19 Magasich, ibíd., p. 137.

20 Carvajal, Fray Gaspar de: Relación del nuevo descubrimiento del famoso río Grande de las Amazonas. México D. F.: FCE, 1955, p. 97.

21 Sir Jehan de Mandeville, ibíd., Cap. XIX, p. 181-2.

22 De Gandía, ibíd., pp. 63 y ss. 
La leyenda de los pueblos impuros

Había también una extraña leyenda de los pueblos impuros: más allá de los confines del mundo, más allá del oriente del Asia, en los extramuros de la humanidad habitaban los pueblos inmundos. Magasich y de Beer ${ }^{23}$ apuntan que en una versión tardía del popular Romance de Alejandro, llamada Pseudo Metodio, ${ }^{24}$ se describe un episodio llamado «El encierro de los pueblos impuros», según el cual Alejandro Magno luchó contra ellos y con la ayuda de Dios los apartó bien lejos de la geografía habitable para que vivieran a su sucio modo:

[...] todos comían cosas asquerosas y repugnantes: perros, moscas, gatos, serpientes, cadáveres, despojos, fetos y embriones que no estaban desarrollados del todo y que no poseían una conformación definida, y no solo animales domésticos, sino de todo tipo de animales impuros. A los muertos no los enterraban, sino que los devoraban. ${ }^{25}$

A veces me pregunto, ¿no son estos «pueblos impuros» los que describe Garcilaso cuando habla de los seres que vivían más allá de los límites de su paradisíaco país de los incas? Leamos el capítulo XII del Libro I de los Comentarios reales:

[Eran ]... amicíssimos de carne humana, y tan golosos, que antes que acabasse de morir el Yndio que matauan, le beuían la sangre

23 Magasich, Jorge y Jean-Marc de Beer, óp. cit., p. 45

24 Sackur, Ernst: Sibyllinische Texte und Forschungen. Pseudomethodius, Adso und die Tiburtinische Sibylle. Halle a. S., 1898, pp. 72-75.

25 Magasich, Jorge y Jean-Marc de Beer, óp. cit., p. 45. La traducción castellana que ofrecen Magasich y de Beer, sin citación, difiere un tanto de la versión latina de Sackur. Esta dice: «...ubi conspexit gentes inmundas et aspectu orribilis. Sunt autem et filiis laphet nepotes, quorum inmundiciam uidens exorruit. Comedebant enit hi honmes cantharo speciem omnen coinquinabilem uel spurcebilem, id est, canes, mures, serpentes, morticinorum carnes, aborticia informabilia corpora et ea que in aluo needum per leniamenta coaculata sunt uel ex aliqua parte membrorum producta conpago forman figmenti possit perficere uultum uel figuram expremere et haec iumentorum necnon etiam et omne speciem ferarum inmundarum. Mortuos autem nequaquam sepeliunt, sed sepe comedent eos». (Cf. Sackur, ídem). 
por la herida que le auían dado, y lo mismo hazían quando lo iuan desquartizando, que chupaban la sangre y se lamían las manos porque no se perdiesse gota della, tuuieron carnecerías públicas de carne humana, de las tripas hazían morcillas, y longanizas, hinchéndolas de carne por no perderlas.

Huuo nación tan estraña en esta golosina de comer carne humana, que enterrauan sus difuntos en sus estómagos, que luego que espiraua el difunto se juntaua la parentela, y se lo comían cozido, o assado, según le auían quedado las carnes, muchas o pocas, y después juntaban los huessos... [etc.]

[...] los hijos que auían (...) se los comían, de manera que hazían seminarios de muchachos para comérselos... ${ }^{26}$

\section{El mundo de los gigantes}

Los gigantes han poblado el imaginario del mundo occidental desde siempre. Los griegos pensaban que en el inicio de los tiempos reinaban los Titanes, una raza de seres gigantescos nacidos de la unión de Urano y Gea. Pero no solo los griegos, sino que también el profeta mesiánico hebreo Baruc hablaba en estos términos: «Allí nacieron los famosos gigantes antiguos de alta estatura y expertos en la guerra. Pero no fue a estos a quienes eligió Dios ni les enseñó el camino de la Ciencia» (Libro de Baruc, Capítulo 3, Versículos 26-27). Y el libro de Marco Polo asignaba una ubicación precisa al mundo de los gigantes; según él, vivían en Zanzíbar y eran grandes, gordos y negros. El Inca Garcilaso en Comentarios reales también habla de los gigantes, solo que dice que eran vecinos nuestros, y vivían por aquí, por nuestro Puerto Viejo en "Tumbes:

[...] vinieron por la mar en vnas balsas de juncos a manera de grandes barcas, vnos hombres tan grandes, que tenía tanto vno dellos de la rodilla abaxo, como vn hombre de los comunes en

26 Garcilaso de la Vega, Inca: Primera parte de los commentaries reales..., Libro I, cip. XII, fol. 12r. ${ }^{\circ}$. 
todo el cuerpo, aunque fuesse de buena estatura (...) era cosa mostruosa ver las cabeças según eran grandes, y los cabellos que les allegauan a las espaldas. Los ojos señalaban que eran tan grandes como pequeños platos... ${ }^{27}$

\section{Las nuevas leyendas de América}

\section{Del Ofir y Tharsis a las leyendas del Perú, el Dorado y el Paititi}

Pero un continente inabarcable, bien pronto se descubrió como un surtidor de leyendas nuevas. Las minas del rey Salomón, que las Sagradas Escrituras llamaban de Ofir y Tharsis, fueron ubicadas por Colón en la isla Española o actual Santo Domingo. En la citada carta al Papa, Colón le dice con toda claridad: «Esta isla es Tharsis, es Cethia, es Ophir y Ophaz e Qipanga, y nos le havemos llamado Española». ${ }^{28}$

\section{La leyenda del Perú}

Pero, en realidad, el inapagable incendio del oro americano recién empezaría a arder aquella fulgurante mañana de 1513 en que un indio, delante de la inmensidad de la Mar del Sur, le cuenta a Balboa del oro del Perú.

Y la leyenda del Perú, como discurso híbrido, indio y español, fue el inicio de todas las demás leyendas del Nuevo Mundo: «Algunos dizen que Balboa tuuo relación de cómo aquella tierra del Perú tenía oro y esmeraldas. Sea así, o no sea, es cierto que auía en Panamá gran fama del Perú». ${ }^{29}$ Es el Inca Garcilaso, repitiendo a Gómara, en los Comentarios reales.

27 Ibid., Libro IX, cap. IX, fol. 234v. ${ }^{\circ}$

28 Colón, Cristóbal: «Carta al Papa Alejandro VI. Febrero, 1502. Fuente: LX1.0AGIS. Patronato 295, 44». En; Cristóbal Colón. Textos y documentos completos. Relaciones de viajes, cartas y memoriales, p. 311.

29 Garcilaso, ibid., Libro I, Cap. VI, fol. 6v. ${ }^{\circ}$ 
Y cuando el Inca arranca a contarle al mundo ilustrado del Renacimiento la increíble leyenda de su patria en su novísimo libro de las maravillas, lo hace de este modo: «[El] Perú tan famoso en el mundo, y con razón famoso, pues a todo él [el mundo] ha llenado de oro y plata, de perlas y piedras preciosas». ${ }^{30}$

\section{El Dorado nace después de Cajamarca}

La enajenación que produjo la leyenda del Dorado fue una consecuencia de la comprobación de la leyenda del Perú, que se había hecho realidad. ${ }^{31}$ En una crónica que se había publicado en Sevilla el año de 1534, Francisco de Xerez, el serísimo secretario de Pizarro, revelaba al mundo sorprendido que en Cajamarca se había ganado tanto oro que circulaba como si se tratara del pan de cada día: "Muchas cosas había que decir (...) de lo poco en que era tenido el oro y la plata. La cosa llegó a que si uno debía a otro algo le daba un pedazo de oro a bulto sin pesar. Y aunque le diese el doble de lo que le debía, no se le daba nada; y de casa en casa andaban los que debían con un indio cargado de oro buscando a los acreedores para pagar". 32

Si en la realidad, si en la historia de los hechos ciertos, la verdad discurría de este modo, por qué en el mundo de los sueños no se podría ya interactuar con lo imposible. Por eso cuando en 1534, en la celeste Quito de los incas, un indio les cuenta a nuestros fundadores que en la aldea de Guatavitá, en la actual Colombia, un cacique cornúpeta había obligado públicamente a su mujer a comerse «las partes de la punidad de su amante», ${ }^{33}$ y que ella se ahogó con su hijito en una laguna sagrada luego de la humillación, pero que el marido arrepentido se vestía con polvos de oro puro por las noches e iba a arrojarle a su difunta, en medio

30 Garcilaso, ibíd, Libro I, Cap. V, f fol. 4v..

31 Gómez-Tabanera, José Manuel: «Presentación». En; Ramos, Demetrio: El ñuto de El Dorado. Madrid: Istmo, 1988, p. VIII y ss.

32 Xerez, Francisco de: Verdadera relación de la conquista del Perú. [1534] Madrid: Historia 16, 1985, p. 152.

33 Magasich, Jorge y Jean-Marc de Beer: America mágica, p. 105. 
de una procesión de fogatas, muchas ofrendas de oro y perlas a la laguna; la tal leyenda tuvo que ser creída de inmediato. Y nuestros fundadores fueron en busca del indio dorado para evitar que siguiera botando el oro al agua, así tan sin razón.

Pero el Dorado no estaba en Colombia. Gonzalo Pizarra que tenía autoridad suficiente para creer ya en todo - y sin asomo de dudas en lo tocante a estas cosassalió del Cuzco hacia 1539, vía Quito, a buscar el Dorado por nuestras selvas (y de pasada el fragante país de la canela). Y, mucho después, en septiembre de 1560 Pedro de Orsúa, desde nuestra Chachapoyas, partió con una expedición en toda regla en busca del Dorado por las selvas del Amazonas, y tuvo que sucumbir en aquella apoteosis de crímenes sin nombre que celebró sin piedad ese «vizcaíno rabioso / muy peor que andaluzado», Lope de Aguirre, como dice de él el romance «Riberas del Marañón». ${ }^{34}$

\section{El Paititi}

Y junto a la leyenda del Dorado nació también en el Perú la leyenda del Jaguar de Oro o Gran Jaguar o Gran Señor del Titi o Paititi, ${ }^{35}$ esa mítica ciudad de oro en las selvas del Manu, en Madre de Dios o en el movedizo país de los Moxos, que se dice habían construido los incas supérstites de la dinastía solar, luego de perder Quito, Cajamarca, el Cuzco y todo su país de los Andes, que ahora se había convertido, sin que acabaran de explicárselo, en el hispano Reino del Perú.

\section{De cómo el Inca cuenta la leyenda de la fuente de la juventud}

El gusto por contar las leyendas de la América española lo inicia el más ilustre escritor peruano en un libro imperecedero: La Florida. Según

34 Coello, Óscar: Los inicios de la poesía castellana en el Perú, p. 317.

35 Tyuleneva, Vera: «La leyenda del Paititi: versiones modernas y coloniales». En: Revista Andina, Cuzco-Perú, N. ${ }^{\circ}$ 36, 2003, p. 193. 
el Inca, el curtido y experimentado $\left(y \operatorname{loco}^{36}\right.$ ) cuarentón ${ }^{37}$ Hernando de Soto, perulero, rico de los más ricos con su parte de Caxamalca, invierte toda su inmensa fortuna ganada en el Perú para iniciar desde España la búsqueda del «gran Reyno de la Florida». ${ }^{38}$

En el discurso literario, la voz del narrador cuenta que la Florida es un país «donde los indios fabulosamente dezían, auía vna fuente que remocaua a los viejos» ${ }^{39}$ y dice que es un reino que limita con las Siete Ciudades Encantadas ${ }^{40}$ de la leyenda (vide ut supra): «Al poniente confina con las prouincias de las siete ciudades ${ }^{41}$

El héroe de la toma de Cajamarca? ${ }^{42}$ «con seys o siete de los conquistadores, que diximos se auían buelto del Perú», ${ }^{43}$ arma una expedición de solo jovencitos: «Nouecientos y cinquenta Españoles (...) todos moÇos, que apenas se hallaua entre ellos vno que tuuiesse canas»; ${ }^{44} \mathrm{y}$, también en el relato, embarca en su nao a una chica de 17 años, doña Leonor de Bobadilla, «dama cuya hermosura era extremada»; ${ }^{45}$ hija natural del conde de la Gomera, una de las islas Canarias, al cual aquel se la solicita «con muchos ruegos y súplicas», ${ }^{46}$ antes de partir para «hacerla gran señora de su nueva conquista»?. ${ }^{47}$

Sin embargo, el narrador prodigioso que es el Inca difumina todos estos datos y los entrevera y encubre tan bien con esa técnica que yo he llamado del espejismo o del espejeo textual y logra distraernos con

36 Garcilaso de la Vega, Inca: La Florida, fol. 2 v..

37 Lockhart, James Marvin: Los de Cajamarca. Un estudio social y biográfico de los primeros conquistadores del Perú. Lima: Milla Batres, 1972. Tomo 2, p. 205, cf. «Notas».

38 Garcilaso de la Vega, el Inca: La Florida, fol. 1 r. ${ }^{\circ}$.

39 Garcilaso, ibíd., Libro I, Cap. II, fol. 3r. .

40 De Gandía, óp. cit., pp. 63 y ss.

41 Garcilaso, ibid., fol. 2v. .

42 Garcilaso de la Vega, Inca: La Florida, fols. 1 r. $^{\circ}$ y lv. ${ }^{\circ}$.

43 Ibíd., Libro I, Cap. VI, fol. 9r. .

44 Ibíd., fol. 9v. ${ }^{\circ}$.

45 Ibíd., Libro I, Cap. VIII, fol. 14r. .

46 ídem.

47 ídem. 
sus explicaciones catolicísimas de que La Florida se llamó así porque se descubrió el día de Pascua de Resurrección o día de Pascua Florida y con la prestidigitación de fechas y pormenores asaz puntuales y agobiantes de quisquilloso historiador. Es necesario acudir al examen de los contenidos latentes para recuperar las posiciones actanciales que no aparecen en el texto, ${ }^{48}$ y así poder saborear la presentación artística y solo artística - subyacente en La Florida- del drama de nuestros fundadores, cual fue el haber alcanzado estas tierras ya maduros, y de no alcanzar a entender cómo después de tantas penurias habían ganado un reino dorado y prodigioso, para tener ante sus ojos la cercana humillación del sepulcro. En el relato, el héroe se muere de una fiebre a los 42 años. ${ }^{49}$

No es necesario recordar que estas empresas descubridoras se sucedían unas tras otras por largos años; en ellas se dejaba la vida o la salud o la juventud. Tal era el precio. Mucha fortuna debió tener aquel que regresó sano y salvo o joven para disfrutar de todo lo ganado. La búsqueda del Reino del Perú (bien lo sabía De Soto) había durado un par de décadas; es decir, se perdieron ahí los mejores años de vida en un mundo donde se era viejo a los cincuenta años. Para los cronistas, Pizarro es un «viejo». Los aventureros partían jovencitos y, al cabo de veinte años o más, eran muy ricos; pero también muy 'viejo[s], cano[s] y pecador[es]', como el verso del romance de «La doncella guerrera». Pizarro tenía 54 años cuando ganó el Perú y las princesas incas con las que anduvo, a él como a todos sus compañeros, acaso los convencieron que el oro del Perú no era nada sin 'la florida del Inca', es decir, «sin la fuente que remojaba a los viejos». Estos hombres no querían ya oro, querían no morir; vivir y ya no envejecer.

Vasco Porcallo de Figueroa se ofreció a Hernando de Soto:

[...] de yr en su compañía a la conquista de la Florida tan famosa, sin que su edad que pasaba ya de los cinquenta años (...) ni la

48 Courtés, Joseph: Análisis semiótico del discurso. Del enunciado a la enunciación. Madrid: Gredos, 1997, p. 113.

49 Garcilaso de la Vega, Inca: La Florida, Libro V, Cap. VII, fol. 270 v..

Bol. Acad. peru. leng. 50(50), 2010 
mucha hazienda ganada y adquirida por las armas, ni el desseo natural que los hombres suelen tener de la gozar, fuesse para resistirle, antes posponiendo todo quizo seguir al Adelantado para lo cual le ofreció su persona, vida y hazienda. ${ }^{50}$

Estoy leyendo el texto original de La Florida, publicado en 1605. A este hombre Hernando de Soto lo hizo su teniente general, deponiendo del cargo a Ñuño Tovar, uno de los jovencitos de la flota descubridora que en un abrir y cerrar de ojos se alzó con la mentada Leonor de Bobadilla de 17 años, y se casó en secreto con ella (el texto dice «clandestinamente» ${ }^{51}$ ), para callado desconsuelo de nuestros héroes maduros. Sin embargo, el escritor llamado a sí mismo, el Inca, cuenta todo esto con su estética del sigilo, con su perfecta e impecable discreción y esa pulquérrima elegancia que aquí admiramos.

Y, luego de habernos prevenido — sagaz ingenio literario, decía del Ynca Menéndez y Pelayo: «es uno de los más amenos narradores que en nuestra lengua pueden encontrarse ${ }^{52}$ — en el puntual paratexto o «Proemio», que no nos va a engañar «con fábulas y fictiones», comienza a encandilarnos con todas las historias asombrosas y alucinantes del viaje en pos de la fuente de la maravilla, prácticamente desde el inicio de su excelso libro, como aquella historia frente al puerto de Santiago de Cuba, donde un exquisito corsario francés y un rico mercader español, hidalgo este de «conversación, tratos y contratos (...) porque ello es lo que hace hidalguías», 53 acordaron no cañonear sus bellas naves para no malograrlas, sino que, en vez de esto, escogieron destrozarse ambos a cuchilladas al frente de sus tripulaciones, pero solo durante el día; porque al caer la noche, pactaron detener el asalto para visitarse en las naos e intercambiar regalos, cortesías y remedios y preguntarse mutuamente por la salud de los heridos y el bienestar personal de los capitanes, y desearse los mejores parabienes, para al amanecer siguiente volver a despedazarse a

50 Ibíd., Libro 1, Cap. XII, fols. 21r. ${ }^{\circ}$ y $21 \mathrm{v}$,

51 Ibíd,. foL 21 v..

52 Menéndez y Pelayo, Marcelino: Historia de la poesía hispanoamericana. Madrid: Librería General de Victoriano Suárez, 1913, tomo II, p. 145.

53 Garcilaso de la Vega, Inca: La Florida, Libro I, Cap. IX, fols. 15 v. $^{\circ}$ y ss. 
sable limpio con mayor furia que el día anterior hasta que llegaba la noche otra vez y se volvían a visitar y a decir cortesías, y así sucesivamente. ${ }^{54}$

Así es la Florida del Ynca, una sucesión deleitosa de relatos e historias alucinantes, como la historia de los indios que se suicidaron colectivamente con sus familias por no querer ir a recoger el oro que se encontraba, dice el narrador, regado a flor de suelo en Santiago de Cuba. ${ }^{55}$

\section{El 'comento y glosa' literarios en La Florida}

Poco a poco, los historiadores severos han ido advirtiendo que ya no podían sostener que lo que leían en La Florida era un documento de hechos verificables, sino que todo rezumaba literatura; arte de escribir. El historiador sanmarquino (y piurano ilustre) don Miguel Maticorena encontró hace ya varias décadas el manuscrito de borrador con los datos históricos que le sirvieron de base a Garcilaso para la redacción final de La Florida del Inca. ${ }^{56}$ Se trata de los apuntes que hizo tomar Garcilaso de su principal informante, Gonzalo Silvestre: «Consta de 40 folios con 79 páginas útiles y ordenado o dividido en 96 parágrafos, pero aún sin títulos ni numeración de capítulos. Es un resumen breve en comparación a la extensa primera edición de 1605. Esta tiene 179 capítulos divididos en seis libros. O sea que el Inca aumentó el resumen de Silvestre con 83 capítulos adicionales, todos sumamente elaborados». ${ }^{57}$ Es decir, La Florida es la reelaboración ficcional de estos apuntes o, para decirlo con palabras del propio Maticorena: «El texto base de la edición de Lisboa es pues el recogido por Silvestre. En 1605, repetimos, aparece sumamente aumentado con escenas y consideraciones con las que el Inca impregnaba de color y animación sus relatos». ${ }^{58}$ Así es, pues, que uno es el texto prosaico con la historia a referir; y el otro, es el arte de narrar del insigne

\footnotetext{
54 ídem.

55 Ibíd., Libro I, Cap. XII, ibis. 20v. ${ }^{\circ}-21$ r. $^{\circ}$.

56 Maticorena Estrada, Miguel: «Un manuscrito de la Florida del Inca Garcilaso». En: El Comercio [Lima], Dominical, 09 de abril de 1989.

57 ídem.

58 ídem.
}

Bol. Acad. peru. leng. 50(50), 2010 
escritor. O, como diría don Marcelino Menéndez y Pelayo, «la historia anovelada» ${ }^{59}$ donde el Inca se muestra insuperable.

\section{De cómo el Inca Garcilaso cuenta la leyenda del Perú}

\section{No tierra, oro}

Hace cuatrocientos años el mundo leía asombrado la existencia de un lugar que cubría todas las apetencias del sueño más terrenal del corazón humano, desde que fue expulsado con razón del Paraíso:

El Oro se coge en todo el Perú: en vnas prouincias es en más abundancia que en otras, pero generalmente lo ay en todo el Reyno. Hállase en la superficie de la tierra, y en los arroyos y ríos donde lo lleuan las auenidas de las lluuias: de allí lo sacan lauando la tierra o la arena, como lauan acá los plateros de escubilla de sus tiendas que son las barreduras dellas. Llaman los Españoles lo que assí sacan Oro en poluo, porque sale como limalla, algunos granos se hallan gruesos de dos tres pesos, y más yo vi granos de a más de 20 pesos, llamantes pepitas, algunas son llanas como pepitas de melón o calabaza, otras redondas, otras largas como hueuos. Todo el Oro del Perú es de diez y ocho a veynte quilates de ley poco más o menos. Solo el que se saca en las minas de Callauaya, o Callahuaya es finíssimo de a veynti quatro quilates, y aun pretende passar dellos según me lo han dicho algunos plateros en España. ${ }^{60}$

Solo quiero resaltar un embrague espacial: el Inca cuenta, según él, para los de «acá», es decir, para sus lectores implícitos «de allá», que son los europeos deseosos de enterarse de la maravilla, o deleitarse con la leyenda del oro del Perú.

59 Menéndez y Pelayo, Marcelino: Orígenes de la novela. Madrid: Consejo Superior de Investigaciones Científicas, 1961, Tomo II, p. 152.

60 Garcilaso de la Vega, Inca: Primera parte de los commentaríos reales..., Libro VIII, Cap. XXIV, fols. $223 \mathrm{v} .^{\circ}$ y $224 \mathrm{r} .^{\circ}$. 


\section{Los incas divinales}

Cuando dibuja el perfil de los incas, los delinea con todas las características de la perfección — sin duda - no humana. Por ejemplo, cuando habla de los príncipes herederos dice así:

[...] eran hijos del Sol, nacidos para enseñar, y hazer bien a los demás, los tenía[n] tan refrenados, y ajustados, que más eran dechado de la República, que escándalo della; dezían con esto que también les faltauan las ocasiones, que suelen ser causa de los delitos, como pasión de mugeres, o cudicia de hazienda o desseo de venganza: porque si desseaban mugeres hermosas, les era lícito tener todas las que quisiessen, y qualquiera moca hermoza que apeteciessen (...). Lo mismo era en la hazienda, que nunca tuuieron falta della para tomarla agena (...). También les faltaua occasión para matar, o herir a nadie por vía de venganza o enojo, porque nadie les podía ofender, antes eran adorados... ${ }^{61}$

Admiremos aquí cómo discurre con suavidad y sabiduría la prosa excelsa de este escritor andino, contemplemos cómo se allega a los misterios que solo alcanzan a tocar las grandes plumas, es decir, él sabe mirar los secretos puntos débiles del corazón humano.

\section{Las orejas de los Incas}

Cuando describe el físico de sus incas divinales escribe así:

“... trayan las orejas horadadas, por donde comúnmente las horadan las mugeres para los carcillos, empero hazían crescer el horado con artificio (...) en estraña grandeza, increíble a quien no la huuiere visto (...) del tamaño y forma de vna rodaja de cántaro..."62

61 Ibíd., Libro II, Cap. XV, fol. 41r. .

62 Ibíd., Libro I, Cap. XXII, fol. 20v. ${ }^{\circ}$.

Bol. Acad. peru. leng. 50(50), 2010 
Es decir, el huequito donde se ensartaban los aretes los incas era del tamaño de la boca de un cántaro.

\section{La historia «anovelada» de los incas conquistadores}

Pero donde se deja ver sin pudor como un narrador altamente ficcional es cuando narra las ceremonias de sujeción de los pueblos vencidos por los incas conquistadores. Después de que el Príncipe Viracocha masacrara a los Chancas, en la que desde entonces sería llamada, pampa de sangre o Yahuarpampa, cuenta nuestro Inca:

...quando llegó a la prouincia (...) de los Chancas, salieron las mugeres y niños que pudieron juntarse con ramos verdes, aclamando y diziendo: Solo señor hijo del Sol, amador de pobres, aued lástima de nosotros, y perdonadnos.

El Príncipe los recibió con mucha mansedumbre, y les mandó dezir, que de la desgracia recebida auían tenido la culpa sus padres, y maridos: y que a todos los que se auían rebelado, los tenía perdonados: y que venía a visitarlos por su persona, para que oyendo el perdón de su propria boca, quedassen más satisfechos, y perdiessen de todo el temor, que podían tener de su delicto. Mandó que les diessen lo que huuiessen menester, y los tratassen con todo amor, y charidad, y tuuiessen gran cuenta con el alimento de las biudas y huérfanos, hijos de los que auían muerto en la batalla de Yahuarpampa. ${ }^{63}$

Naturalmente, en el discurso directo, sin la menor duda, ficcional, vemos cómo los chancas hablan como españoles («aued lástima de nosotros y perdonadnos»). Y en el discurso indirecto de Viracocha vemos que hay un príncipe inca que sabe muy bien qué es el amor, qué es el perdón y qué es la caridad cristiana, aunque haya acabado de inaugurar Yahuarpampa o campo de sangre.

63 Ibíd, Libro V, Cap. XX, fols. 118r. y 118v.". 


\section{No había pobres}

Claro que ningún historiador serio creerá aquello que cuenta el Inca escritor acerca de la sociedad perfecta donde no había pobres, pero nuestro amado y excelso narrador se lo hizo creer así aun a los ilustradísimos enciclopedistas franceses, y a tantos otros a quienes puso a soñar con las sociedades perfectas o utópicas: «De manera que lo necessario para la vida humana de comer, y vestir y calcar lo tenían todos, que nadie podía llamarse pobre, ni pedir limosna, porque lo vno y lo otro tenían bastantemente, como si fueran ricos». ${ }^{64}$

\section{El tributo de los pobres}

Y también Garcilaso ha contado sin rubor que en la sociedad altamente planificada de los incas cuando alguien no tenía para pagar los impuestos, podía pagar con sus piojos:

1...] otra manera de tributo dauan los impedidos, que llamamos pobres, y era que de tantos a tantos días eran obligados a dar a los gouernadores de sus pueblos ciertos cañutos de piojos. (...) se lo pedían de piojos, porque como pobres impedidos no podían hazer seruicio personal, que era el tributo que todos pagauan. Pero también dezían, que la principal intención de los Incas para pedir aquel tributo, era zelo amoroso de los pobres impedidos, por obligarles a que se despiojassen, y limpiassen, porque como gente desastrada no pareciessen comidos de piojos: por este zelo que en toda cosa tenían los Reyes, les llamauan amadores de pobres. ${ }^{65}$

Demás está decir que la afirmación anterior de que no había pobres queda contradicha; pero no importa, así es el Inca. En el mundo de la literatura todo puede ocurrir. El Inca escritor solo está ejecutando con maestría su excelsa partitura barroca de diestro narrador, es decir, aderezando una leyenda.

64 Ibíd., Libro V, Cap. IX, fol. 107r..

65 Ibíd., Libro V, Cap. VI, fol. 105r. ${ }^{\circ}$.

Bol. Acad. peru. leng. 50(50), 2010 


\section{La religión de Manco Cápac, el lucero del alba}

Confieso que uno de los relatos que más me conmueven de este anciano de 70 años que escribía con los ojos cerrados pensando en su patria lejana es cuando dice que los intelectuales incas lograron conceptualizar al Dios nuestro:

“[...] los Reyes Yncas, y sus Amautas, que eran los Philósophos rastrearon con lumbre natural al verdadero sumo Dios, y Señor nuestro, que crió el cielo y la tierra, como adelante veremos en los argumentos y sentencias, que algunos dellos dixeron de la diuina Magestad: al qual llamaron Pachacamac". ${ }^{66}$

Y me conmueve ver cómo acude a la figura cristológica del Lucero del Alba para explicar a su inca Manco Cápac. En las últimas líneas del Libro de las Revelaciones o Apocalipsis, Jesús se define a sí mismo como el Lucero del Alba; leamos ahora este curioso texto garcilasino:

Viuiendo, o muriendo aquellas gentes de la manera que hemos visto, permitió Dios nuestro Señor, que dellos mismos saliesse vn luzero del alua [Manco Cápac], que en aquellas escuríssimas tinieblas les diesse alguna noticia de la ley natural, y de la vrbanidad y respetos, que los hombres deuían tenerse vnos a otros, y que los descendientes de aquel, procediendo de bien en mejor, cultiuassen aquellas fieras y las conuirtiessen en hombres, haziéndoles capaces de razón, y de qualquiera buena dotrina: para que quando esse mismo Dios, sol de justicia, tuuiesse por bien de embiar la luz de sus diuinos rayos a aquellos idólatras, los hallasse no tan saluajes, sino más dóciles para recebir la fe Cathólica, y la enseñanza y doctrina de nuestra sancta madre Yglesia Romana. ${ }^{67}$

Y, me conmueve más, cuando dice que veneraron la Santa Cruz:

66 Ibíd., Libro II, Cap. II, fol. 26r. ${ }^{\circ}$

67 Ibíd., Libro I, Cap. IV, fol. 13v. ․ 
Tvuieron los Reyes Incas en el Cozco vna cruz de mármol fino de color blanco, y encarnado, que llaman jaspe cristalino: no saben dezir desde qué tiempo la tenían. (...) La cruz era quadrada tan ancha como larga, tendría de largo tres quartas de vara, antes menos que más, y tres dedos de ancho, y casi otro tanto de grueso era enteriza toda de vna pieça mui bien labrada con sus esquinas muy bien sacadas, toda pareja, labrada de quadrado, la piedra muy bruñida y lustrosa. Teníanla en vna de sus casas reales en vn apartado de los que llaman Huaca, que es lugar sagrado. No adorauan en ella, mas de que la tenían en veneración, deuía ser por su hermosa figura, o por algún otro respecto que no saben dezir. Assí la tuuieron hasta que el marqués don Francisco Piçarro entró... ${ }^{68}$

\section{El Inca Garcilaso y la leyenda del Perú}

Para terminar. Decía el Maestro de Santander, don Marcelino Menéndez y Pelayo, de este libro insigne: «Los Comentarios reales no son texto histórico, son una novela». ${ }^{69}$ En otro momento, escribe el sabio santanderino, refiriéndose a la Florida del Inca y a los propios Comentarios reales, «la celebridad de Garcilaso, como uno de los más amenos y floridos narradores que en nuestra lengua pueden encontrarse, se funda en sus obras historiales, que mejor clasificadas estarían (sobre todo la segunda) de historias anoveladas». ${ }^{70} \mathrm{Y}$ también dice, refiriéndose al trabajo artístico de nuestro primer escritor, que «se formó en el espíritu de Garcilaso lo que pudiéramos llamar la novela peruana o la leyenda incásica». ${ }^{71}$

No voy a afirmar ni negar nada. Solo voy a citar algunos textos entresacados de la inmensa prosa oceánica del Inca, que a mi juicio son reveladores de su magistral juego artístico. En el capítulo XIX de

\footnotetext{
68 Ibíd., Libra II, Cap. III, fols. $27 \mathrm{v} .^{\circ}$ y $28 r^{\circ}$.

69 Menendez y Pelayo, Marcelino, ibid., p. 153.

70 Ibid., p. 152.

71 Ibid., p. 153.
}

Bol. Acad. peru. leng. 50(50), 2010 
los Comentarios, no sin razón titulado: «Protestación del autor sobre la historia», la voz del narrador retorna a la instancia de la enunciación y se descubre ante su lector en la soledad del acto de la lectura, y le instruye de sus propósitos: «... al discreto lector suplico reciba mi ánimo, que es de darle gusto y contento». ${ }^{72} \mathrm{Y}$ eso se llama literatura.

Su trabajo de entroncar la leyenda del Perú con el mundo fabuloso de la cultura occidental (el profano y el divino), que hemos referido temprano, puede notarse en frases como esta: «el que las leyere, podrá cotejarlas a su gusto, que muchas hallará semejantes a las antiguas, así de la sancta escritura, como de las profanas y fábulas de la gentilidad antigua». ${ }^{73}$ No lo olvidemos al estudiarlo.

Y en otra ocasión para aclarar que lo que cuenta es leyenda, encanto, belleza para disfrutar, dice de sus informantes, los incas ficcionales: «Me contaban sus historias como se cuentan las fábulas a los niños». ${ }^{74}$

Y nadie puede negarle esa habilidad para hacer creer lo imposible. Un escritor es más fino cuando atrapa al lector; pero, sobre todo, cuando no le deja ver los términos del embuste artístico; cuando lo hace transitar sin que se dé cuenta entre el mundo de la realidad y el mundo de la ficción; cuando no le permite percatarse de que está soñando, cuando él mismo lo ha puesto a soñar. Pero este Inca escritor no solo es fino, es genial, le dice al lector que le está entreverando la realidad con la ficción, la verdad con la fábula, y el lector se resiste a ser desengañado: «ampliamos y estendemos con la propia relación la que los historiadores españoles como extrangeros acortaron por no saber la propiedad de la lengua ni auer mamado en la leche aquestas fábulas y verdades como yo las mamé». ${ }^{75}$

72 Garcilaso de la Vega, Inca: Primera parte de los commentarios reales..., Libro I, Cap. XIX, fol. 19r. .

73 ídem.

74 ídem.

75 Ibíd., Libro II, Cap. X, fol. 37r. ${ }^{\circ}$. 


\section{Ultílogo}

En una de esas tardes de Dios en que disfrutaba por enésima vez de la prosa del Inca, me topé con una frase dicha, como todas las suyas, casi al desgaire. Así define Garcilaso el Perú: «Mi patria (yo llamo assí a todo el Imperio que fue de los Incas)»;76 y desde ese entonces, yo también así defino con orgullo al mío: «Mi patria (llamo assí al país que fue de los Incas)». Ahora es nuestro. Un país nacido en el esplendor de una hermosa leyenda.

\section{BIBLIOGRAFÍA}

BENEDE1T y Jehan de Mandeville. Libros de maravillas. Madrid: Ed. Siruela, 2002

CARVAJAL, Fray Gaspar de. Relación del nuevo descubrimiento del famoso río Grande de las Amazonas. México D. F.: FCE, 1955.

COELLO, Óscar. Los inicios de la poesía castellana en el Perú. 2. ed. Lima: PUCPFondo Editorial, 2001.

. Los orígenes de la novela castellana en el Perú. La toma del Cuzco (1539). Lima: Academia Peruana de la Lengua- Unidad de Posgrado de la Facultad de Letras y Ciencias Humanas de la Universidad Nacional Mayor de San Marcos, 2008.

COURTÉS, Joseph. Análisis semiótico del discurso. Del enunciado a la enunciación. Madrid: Gredos, 1997.

FERNÁNDEZ DE OVIEDO, Gonzalo. Historia general y natural de las Indias, Islas y Tierra-Firme del Mar Océano. Madrid: Imprenta de la Real Academia de la Historia, 1855.

76 Ibíd., Libro IX, Cap. XXIV. 249 r. ${ }^{\circ}$ y v. ${ }^{\circ}$

Bol. Acad. peru. leng. 50(50), 2010 
GANDÍA, Enrique de. Historia crítica de los mitos y leyendas de la conquista americana. [1929]. BB. AA.: Centro Difusor del Libro, 1946.

GARCILASSO DE LA VEGA, el Ynca. Primera parte de los commentarios reales, que tratan del origen de los Yncas, reyes que fueron del Perú, de sv idolatría, leyes, y gouierno en paz y en guerra: de sus vidas y conquistas, y de todo lo que fue aquel Imperio y su República, antes que los españoles passaran a él. Lisboa: En la oficina de Pedro Crasbeeck, MDCIX.

GARC1LASO DE LA VEGA, Inca. La Florida del Ynca. Lisbona: Impresso por Pedro Crasbeeck, 1605.

GÓMEZ-TABANERA, José Manuel. «Presentación». En: Ramos, Demetrio: El mito de El Dorado. Madrid: Istmo, 1988.

ISIDORO DE SEVILLA (San). Etimologías. Madrid: Biblioteca de Autores Cristianos, 1983.

LOCKHART, James Marvin. Los de Cajamarca. Un estudio social y biográfico de los primeros conquistadores del Perú. Tomo 2. Lima: Milla Batres, 1972.

MAGASICH, Jorge y Jean-Marc de Beer. América mágica. Mitos y creencias en tiempos del descubrimiento del Nuevo Mundo. Santiago de Chile: Lom-Ediciones, 2001.

MATICORENA, Miguel. «El vasco Pascual de Andagoya inventor del nombre del Perú». En: Cielo Abierto. Lima, Vol. II, N. ${ }^{\circ}$ 5, octubre 1979.

. «Un manuscrito de la Florida del Inca Garcilaso». En: El Comercio [Lima], Dominical, 09 de abril de 1989. 
MENÉNDEZ Y PELAYO, Marcelino. Orígenes de la novela. Tomo IL Madrid: Consejo Superior de Investigaciones Científicas, 1961.

Historia de la poesía hispanoamericana. Tomo II. Madrid: Librería General de Victoriano Suárez, 1913.

SACKUR, Ernst. Sibyllinische Texte und Forschungen. Pseudomethodius, Adso und die Tiburtinische Sibylle. Halle a. S., 1898.

TYULENEVA, Vera. «La leyenda del Paititi: versiones modernas y coloniales». En: Revista Andina, Cuzco-Perú, N. ${ }^{\circ}$ 36, 2003.

VARELA, Consuelo (Ed., pról. y notas). Cristóbal Colón. Textos y documentos completos. Relaciones de viajes, cartas y memoriales. Madrid: Alianza Editorial, 1984.

XEREZ, Francisco de. Verdadera relación de la conquista del Perú. [1534]. Madrid: Historia 16, 1985.

\section{Correspondencia:}

\section{Óscar Coello}

Docente de la Facultad de Letras y Ciencias Humanas de la Universidad Nacional Mayor de San Marcos.

Correo electrónico: ocoello@ oscarcoello.com 